\section{Elaborarea tehnologiilor de cultivare şi prelucrare a strugurilor de selecție nouă cu aromă de muscat}

Mihail CUHARSCHI, doctor habilitat în științe agricole, conferenţiar cercetător, https://orcid.org/0000-0002-4823-7619, e-mail: vierul isphta@bk.ru;

Vitalie CEBANU, doctor în științe agricole, conferenţiar cercetător, https://orcid.org/0000-0003-3022-2432, e-mail:cebanu-vitalii@mail.ru;

Nicolae TARAN, doctor habilitat în științe tehnice, profesor universitar, https://orcid.org/0000-0003-1683-0378, e-mail: taraninvv@yahoo.com;

Boris GAINA, doctor habilitat, profesor universitar, academician al AȘ, https://orcid.org/0000-0002-3536-1477, e-mail: b.gaina@mail.ru;

Vladimir DEGTEARI, doctor în științe agricole, conferenţiar cercetător, https://orcid.org/0000-0002-1156-9716 IP Institutul Stiințifico-Practic de Horticultură și Tehnologii Alimentare

Rezumat. În lucrarea de faţă sunt prezentate date privind originea, agrobiologia, elementele de bază ale agrotehnicii varietale specifice soiurilor cu aromă de muscat, obţinute din încrucișări interspecifice în cadrul IŞPHTA. Sunt oferite informaţii despre rezistenţa lor complexă la factorii biotici şi abiotici, particularităţile protecţiei contra bolilor şi dăunătorilor. Se arată influenţa proceselor tehnologice de prelucrare a strugurilor asupra conţinutului de substanţe terpenice (aromatice) în vinuri.

Cuvinte-cheie: soiuri aromate (cu aromă de muscat), agrobiologie, agrotehnică varietală, protecţie, procesarea strugurilor.

*Agrotehnică varietală (de soi) - tehnici agricole specifice, aplicate în corespundere cu proprietăţile agrobiologice, caracteristice fiecărui soi.

Summary. This paper presents data on the origin, agrobiology, basic elements of varietal agrotechnics specific to flavored varieties, obtained from interspecific cracks in the ISPHTA. Information is provided on their complex resistance to biotic and abiotic factors and the characteristics of protection against diseases and pests. The influence of the grape processing scheme on the content of terpene (aromatic) substances in wines is shown

Keywords: aromatic varieties (with geranium flavor), agrobiology, varietal agrotechnics, protection, grape processing.
În Republica Moldova, în anii 1950-1990, odată cu introducerea pe scară largă a soiurilor nobile de struguri o atenţie deosebită s-a acordat creării de noi hibrizi interspecifici cu rezistenţă complexă la boli şi dăunători, ger şi condiţiile neprielnice de mediu (secetă, fluctuaţiile de temperatură din timpul iernii ş.a.). Amelioratorii, agrotehnicienii şi vinificatorii din Republica Moldova pe parcursul a mai bine de 50 de ani de activitate ştiinţifică au creat şi au introdus în producţie diverse soiuri de selecţie nouă, inclusiv o serie de soiuri aromatice cu rezistenţă sporită la factorii biotici şi abiotici, care întrunesc şi cerinţele necesare pentru obţinerea vinurilor ecologice (organice) cu aromă de muscat $[1,2,3]$.

Soiurile noi aromatice cu rezistenţă sporită la factorii biotici şi abiotici prezintă un interes deosebit atât pentru oenologi, datorită aromei specifice a vinurilor cauzată de compuşii terpenici concentraţi în pieliţa şi straturile adiacente ale pulpei bobiţelor, cât şi pentru viticultori, datorită oportunităţilor economice care le permit să reducă costurile lucrărilor de protejare a noilor plantaţii de ger, boli şi dăunători.

Utilizarea tulpinilor speciale de drojdii [4, 7] în procesul de obţinere a vinurilor albe seci şi a celor spumante a oferit posibilitatea obţinerii (sintetizării) a unor concentraţii mai sporite de compuşi terpenici cu manifestarea maximă a potenţialului aromatic în vin, care este foarte important pentru obţinerea unor producţii vinicole de înaltă calitate, competitivă pe pieţele externe şi interne.

\section{MATERIAL ȘI METODE DE CERCETARE}

Cercetările au fost efectuate în perioada anilor 2000-2020 în colecţia de soiuri şi în plantaţiile experimentale viticole ale IŞPHTA. Viile au fost susţinute pe spalier monoplan vertical. Distanţa între rânduri a variat de la 2,5-2,8 până la 3,0 m, în funcţie de forma butucilor şi fertilitatea solului. Distanţa de plantare a butucilor pe rând (pasul plantării) pentru soiurile cu vigoare medie de creştere a fost de $1,25 \mathrm{~m}$, pentru cele cu creşterea medie-viguroasă - de 1,5 m; pentru formele de talie mică (de tip Guyot şi altele similare), pe pante uscate şi slab fertile, pasul plantării a fost de 1,0-1,2 m.

Conform metodelor de cercetare în agrotehnică [5], s-a luat în evidenţă comportarea diferitor soiuri noi cu arome de muscat în condiţiile de climă şi sol ale Republicii Moldova, pe baza efectuării evidenţelor agrobiologice şi determinării indicilor mai importanţi: calitatea şi cantitatea medie a producţiei de struguri, gradul de maturare a coardelor, starea ochilor şi a ţesuturilor după iernare.

Programele de protecţie contra organismelor nocive au fost elaborate în baza datelor obţinute pe parcur- 
sul a mai multor ani de cercetare în cadrul laboratorului „Imunologie şi protecţie a viţei-de-vie" al IŞPHTA [1, 2, $8,9]$, folosind metode fitopatologice de cercetare [6].

Determinarea indicilor fizico-chimici ai mustului și vinurilor s-a efectuat după metode cunoscute $[4,8]$.

\section{ANALIZA REZULTATELOR OBȚINUTE}

Caracteristicile agrobiologice şi agrotehnice. Rezultatele obţinute pe parcursul a mai multor ani de cercetare (anii '70-'90 ai secolului XX) a noilor soiuri de struguri cu arome de muscat sunt prezentate în tabelul 1 (fig.1). Soiuri noi de vin: Viorica, Muscat de laloveni, Muscat basarabean, Muscat de Onițcani, Co- dru, şi cu destinaţie universală - Startoviî, Muscat de Bugeac etc. au fost identificate ca fiind cele mai stabile şi productive. Aceste soiuri se caracterizează printr-o perioadă de coacere medie şi medie-tardivă, creştere medie şi medie-viguroasă. În cazul amplasării soiurilor cu vigoare medie de creştere pe soluri mai productive, butucii se dezvoltă mai viguros. Recolta medie de struguri a variat, în funcție de soi, de la 8-10 la 1416 t/ha. Condiţiile de calitate a mustului s-au încadrat în cerinţele prevăzute pentru producţia de vinuri albe seci şi a celor spumante cu aromă de muscat.

Majoritatea soiurilor posedă caractere de rezistenţă la ger şi la condiţiile de iernare şi se cultivă în cultură neprotejată - pe tulpină înaltă. După ierni

\section{Particularitățile agrobiologice şi elementele de bază ale agrotehnicii varietale (de soi) specifice cultivarelor de selecție nouă cu aromă de muscat, IŞPHTA}

\begin{tabular}{|c|c|c|c|c|c|c|c|c|c|}
\hline $\begin{array}{c}\text { Soiuri autohtone cu aromă de } \\
\text { muscat }\end{array}$ & 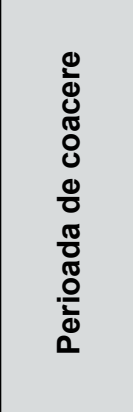 & 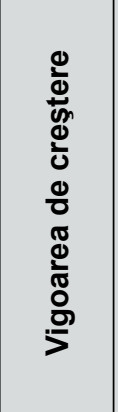 & 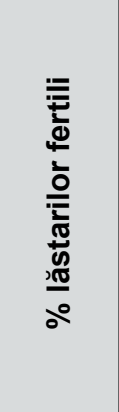 & 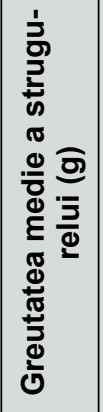 & 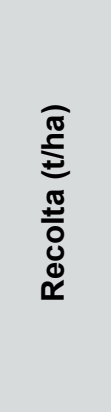 & 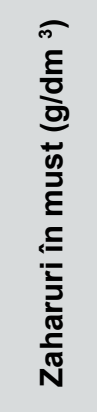 & 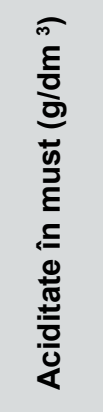 & 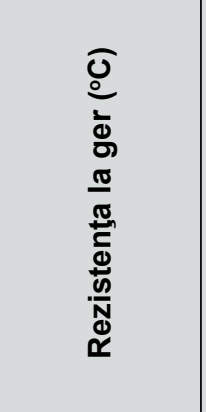 & 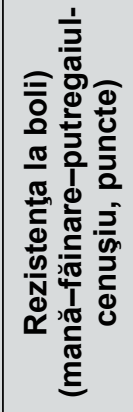 \\
\hline \multicolumn{10}{|c|}{ SOIURI PENTRU VIN } \\
\hline $\begin{array}{l}\text { Viorica Cl. M-1 } \\
\text { Zeibel 13-666 x Aleatico }\end{array}$ & medie & medie & $80-90$ & \begin{tabular}{|c|}
$134-$ \\
154 \\
\end{tabular} & 8-12 & $\begin{array}{l}180- \\
210\end{array}$ & $7-9$ & $\begin{array}{l}\text { sporită } \\
\left(-23^{\circ} \mathrm{C}\right)\end{array}$ & $\begin{array}{c}\text { sporită } \\
3-3-2\end{array}$ \\
\hline $\begin{array}{l}\text { Muscat de laloveni } \\
\text { Zeibel 13-666 x Aleatico }\end{array}$ & $\begin{array}{l}\text { medie } \\
\text { tardivă }\end{array}$ & medie & $>70$ & \begin{tabular}{|l|}
$230-$ \\
250
\end{tabular} & $10-12$ & $\begin{array}{l}180- \\
210\end{array}$ & $8-10$ & $\begin{array}{l}\text { sporită } \\
\left(-25^{\circ} \mathrm{C}\right)\end{array}$ & $\begin{array}{c}\text { sporită } \\
3-3-3\end{array}$ \\
\hline $\begin{array}{l}\text { Muscat basarabean } \\
\text { Zeibel 13-666 x Aleatico }\end{array}$ & medie & medie & $60-80$ & 206 & $11-12$ & $\begin{array}{l}190- \\
210\end{array}$ & $9-10$ & $\begin{array}{l}\text { Sporită } \\
\left(-23^{\circ} \mathrm{C}\right)\end{array}$ & $\begin{array}{c}\text { Medie } \\
3-3-4 \\
\end{array}$ \\
\hline $\begin{array}{l}\text { Muscat de Oniţcani } \\
\text { CB-20-473 (selecţie pe fon } \\
\text { infecţios) }\end{array}$ & medie & medie & $80-84$ & 195 & $9-12$ & $\begin{array}{l}180- \\
200\end{array}$ & $8-9$ & $\begin{array}{c}\text { relativă } \\
\left(-20-22^{\circ} \mathrm{C}\right)\end{array}$ & $\begin{array}{l}\text { sporită } \\
\text { 3-3-3- }\end{array}$ \\
\hline $\begin{array}{l}\text { Codru (Muscat Oberlen x } \\
\text { CB-20-375 cu CB 20-366 şi } \\
\text { descendentul hibrid 244) }\end{array}$ & $\begin{array}{l}\text { medie } \\
\text { tardivă }\end{array}$ & medie & 75 & 145 & $10-12$ & $\begin{array}{l}170- \\
200\end{array}$ & 7,9-9 & $\begin{array}{c}\text { medie } \\
\text { înaltă } \\
\left(-22-23^{\circ} \mathrm{C}\right)\end{array}$ & $\begin{array}{l}\text { sporită } \\
3-3-3\end{array}$ \\
\hline \multicolumn{10}{|c|}{ SOIURI UNIVERSALE (de masă şi pentru vin) } \\
\hline $\begin{array}{l}\text { Startovîi } \\
\text { (Muscat Derbentschi x } \\
\text { Muscat de St. Vallier) }\end{array}$ & medie & medie & $70-80$ & $\begin{array}{c}450- \\
500\end{array}$ & $12-13$ & $\begin{array}{l}170- \\
200\end{array}$ & 7-8 & $\begin{array}{l}\text { sporită } \\
\left(-24^{\circ} \mathrm{C}\right)\end{array}$ & $\begin{array}{l}\text { medie } \\
4-3-3\end{array}$ \\
\hline $\begin{array}{l}\text { Muscat de Bugeac } \\
\text { (Coarnă neagră x } \\
\text { Muscat de St. Vallier) }\end{array}$ & medie & medie & 75 & 310 & $10-11$ & $\begin{array}{l}180- \\
200\end{array}$ & 8 & $\begin{array}{l}\text { sporită } \\
\left(-23^{\circ} \mathrm{C}\right)\end{array}$ & \begin{tabular}{|l} 
medie- \\
slabă \\
$4-4-3$ \\
\end{tabular} \\
\hline $\begin{array}{l}\text { Avgustovski } \\
\text { CB-18-315 x Jemciug Sabo }\end{array}$ & medie & medie & 86 & \begin{tabular}{|l|}
$180-$ \\
200 \\
\end{tabular} & 12 & $\begin{array}{c}165- \\
190 \\
\end{array}$ & $6-7$ & $\begin{array}{l}\text { sporită } \\
\left(-25^{\circ} \mathrm{C}\right)\end{array}$ & $\begin{array}{l}\text { sporită } \\
3-3-3\end{array}$ \\
\hline $\begin{array}{l}\text { Frumoasa albă } \\
\text { Guzeli Cara x Muscat de } \\
\text { St. Vallier) }\end{array}$ & $\begin{array}{c}\text { medie } \\
\text { preco- } \\
\text { ce }\end{array}$ & \begin{tabular}{|c|} 
medie \\
vigu- \\
roasă \\
\end{tabular} & 80 & 404 & $12-14$ & $\begin{array}{c}160- \\
170\end{array}$ & 7,5 & $\begin{array}{l}\text { sporită } \\
\left(-23^{\circ} \mathrm{C}\right)\end{array}$ & $\begin{array}{c}\text { sporită } \\
4-3-3\end{array}$ \\
\hline $\begin{array}{l}\text { Muscat de Hamburg } \\
\text { Muscat de Alexandria x Fran- } \\
\text { kenthal (Black Hamburgh) - } \\
\text { ETALON }\end{array}$ & $\begin{array}{l}\text { medie } \\
\text { tardivă }\end{array}$ & $\begin{array}{l}\text { medie } \\
\text { slabă }\end{array}$ & $60-80$ & \begin{tabular}{|l|}
$225-$ \\
320
\end{tabular} & $\begin{array}{l}\text { 9-10 } \\
\text { până } \\
\text { la } 12\end{array}$ & $\begin{array}{l}160- \\
220\end{array}$ & $6,7-9$ & $\begin{array}{c}\text { slabă şi } \\
\text { medie } \\
\left(-19-20^{\circ} \mathrm{C}\right)\end{array}$ & $\begin{array}{l}\text { sensi- } \\
\text { bil } \\
5-5-4\end{array}$ \\
\hline
\end{tabular}




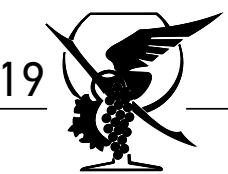

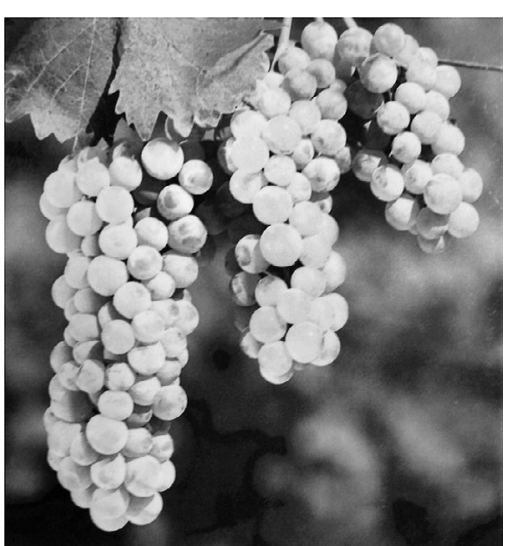

Viorica

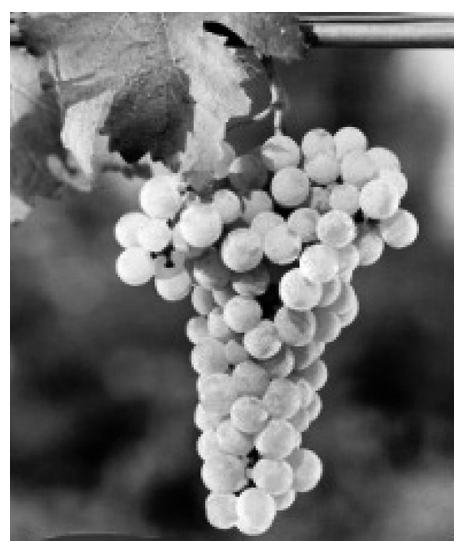

Muscat de Ialoveni

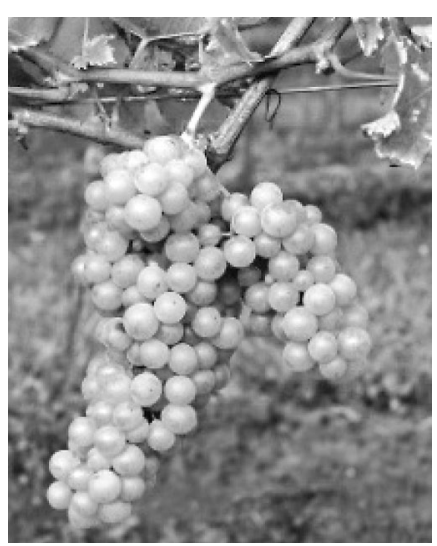

Muscat basarabean

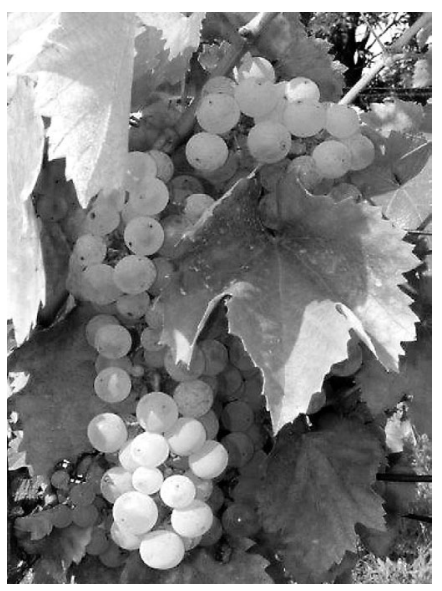

Muscat de Onițcani

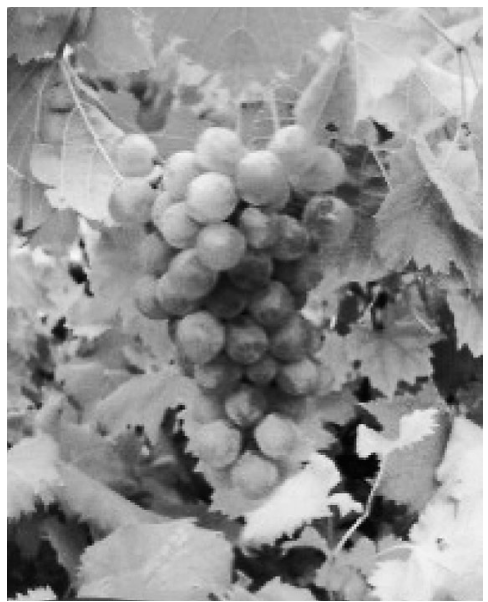

Avgustovski

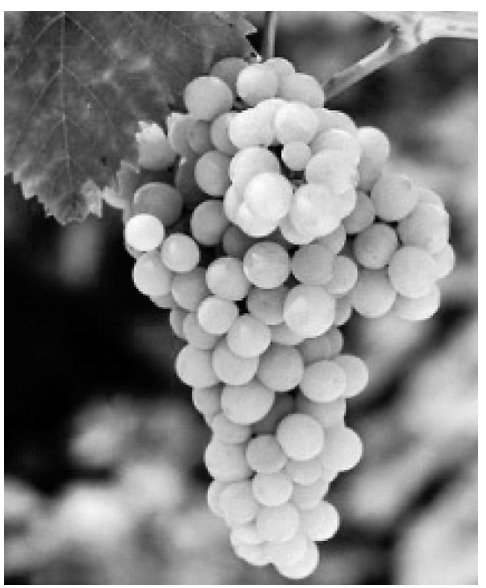

Startovîi

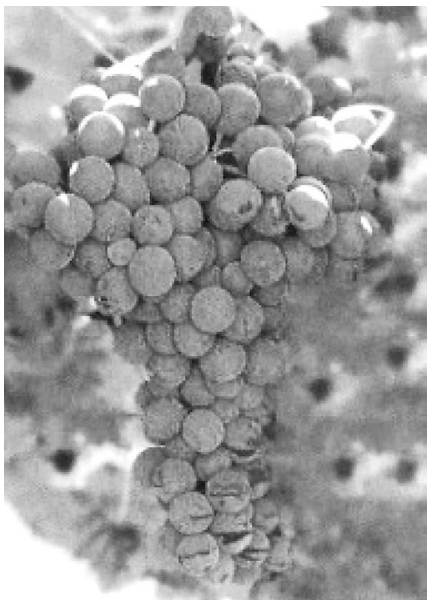

Muscat de Hamburg

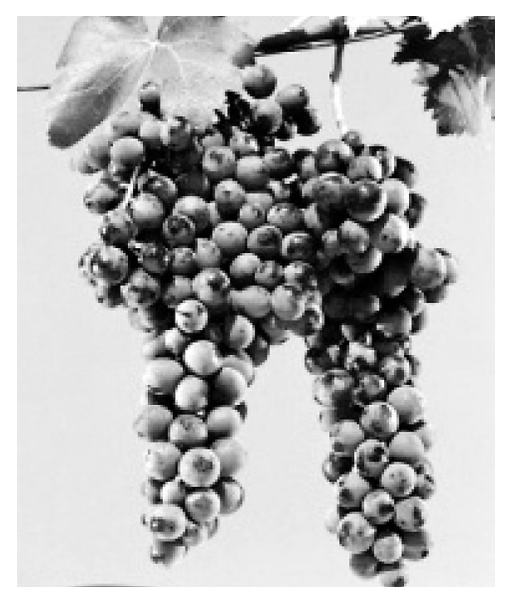

Muscat de Bugeac

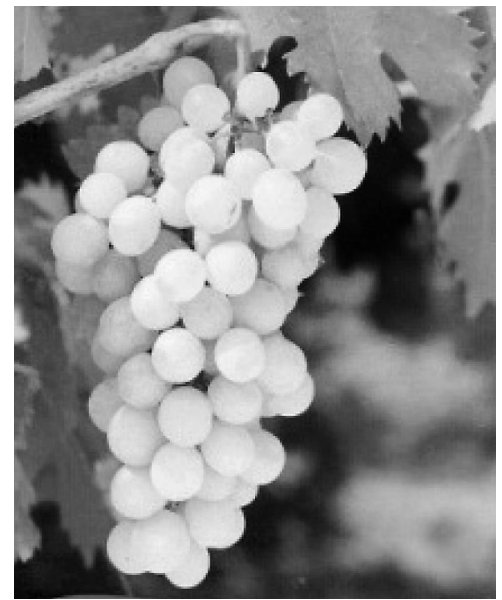

Frumoasă albă

Figura 1. Noi varietăți de struguri cu aromă de muscat create în cadrul IȘPHTA

deosebit de geroase, acestea îşi restabilesc productivitatea datorită capacităţii înalte de regenerare a organelor afectate. Butucii fructifică stabil la atribuirea unor sarcini moderate, aplicând tăierea scurtă şi medie a elementelor de rod (la tăierea în uscat) după schema: $2+3-4$ şi $2+5-7$ ochi. Sunt preferabile formele de cordon şi de evantai pe tulpină medie
(Moldovenească cu 2 tulpini, cordon Kazenava, cu un singur braţ, evantai pe tulpină).

Menţionăm că în ultimii ani se practică susţinerea pe spalier metalic „profil metallic” cu 4 niveluri de sârme duble, care permit dirijarea cât mai bună a lăstarilor în spaţiu, cu cheltuieli reduse, sporind astfel productivitatea muncii. Plantaţiile de soiuri noi sunt cultivate 
prin metode ecologice cu tratamente chimice limitate împotriva bolilor şi dăunătorilor, datorită rezistenţei complexe la factorii biotici.

\section{Particularităţile de protecţie a soiurilor aromate cu rezistenţă sporită la principalele boli de origine micotică}

Soiurile aromatice Viorica, Muscat de laloveni, Muscat basarabean, Muscat de Onițcani ş.a., manifestând, în majoritatea lor, rezistenţă sporită la bolile criptogamice, necesită sisteme de protecţie cu număr redus de tratamente. Aceasta permite utilizarea lor în programe ecologice de producţie vitivinicolă cu folosirea limitată a sărurilor simple pe bază de sulf şi cupru în conformitate cu principiile de agricultură ecologică, elaborate de Federaţia Internaţională a Mişcărilor pentru Agricultură Ecologică (IFOAM).

Trebuie însă să constatăm că în anii cu ploi abundente, la început de vegetaţie, soiurile din această grupă pot fi afectate de antracnoză şi rujeolă, boli secundare, care pot influenţa negativ cantitatea şi calitatea producţiei de struguri. Astfel, în condiţii de ploi de lungă durată, frecvente la începutul vegetaţiei viţei-de-vie (în perioadele de dezmugurire şi creştere intensivă a lăstarilor), pentru prevenirea antracnozei şi rujeolei în stadiul apariţiei a trei frunze adevărate, se va aplica un tratament cu utilizarea unui produs pe bază de cupru (sulfat de cupru, hidroxid de cupru, sulfat tribazic de cupru ş.a.) în dozele recomandate. În cazul în care condiţiile vor continua să fie favorabile pentru manifestarea patogenilor (se vor înregistra ploi de lungă durată în perioada de creştere intensivă a lăstarilor), contra bolilor se va realiza un alt tratament cu utilizarea produselor cuprice în stadiul când lăstarii ating lungimea de $25-30 \mathrm{~cm}$. În acest stadiu de dezvoltare a viţei-devie la aplicarea tratamentelor este recomandată utilizarea unui volum de $400 \mathrm{l} / \mathrm{ha}$ [8].

Menţionăm că datorită spectrului larg de acţiune, produsele cuprice aplicate la începutul perioadei de vegetaţie joacă un rol important în profilaxia şi în prevenirea unor astfel de boli ale lemnului: excorioza (Phomopsis viticola Sacc.) şi eutipioza (Eutypa armeniaceae Hansf.) - patologii care în cazuri grave produc uscarea lemnului (braţelor, tulpinii şi integral a butucului). Potrivit unor date [10], utilizarea produselor cuprice la început de vegetaţie (în primul tratament) exercită o acţiune inhibitoare asupra dezvoltării făinării viţei-de-vie. În anii secetoşi, în lipsa condiţiilor pentru dezvoltarea antracnozei şi rujeolei, nu se aplică tratamentele anticriptogamice în perioada de până la înflorit.

Primul tratament contra manei se va aplica în stadiul de „răsfirare a inflorescenţelor”, cu utilizarea produselor cuprice. În această perioadă tratamentul este obligatoriu (de siguranţă) pentru protecţia organelor generative (inflorescenţelor). Tratamentul se aplică cu un consum de soluţie de $600 \mathrm{l} / \mathrm{ha}$ şi este eficient şi în combaterea antracnozei şi pătării roşii.

De regulă, în această perioadă tratamente contra făinării nu se aplică. Se va lua decizia de aplicare a tratamentului antioidic cu utilizarea preparatelor pe bază de sulf în situaţiile în care apar condiţii cu risc de afectare (s-au înregistrat infecţii de făinare în anul precedent; condiţiile ecologice predispun atacului de făinare: plantaţiile sunt amplasate în depresiuni, în apropierea lacurilor, râurilor, unde umiditatea relativă a aerului este mai favorabilă dezvoltării bolii sau condiţiile climatice favorizează atacurile de făinare: timp secetos cu ploi de scurtă durată, vânturi moderate).

Un al doilea tratament de siguranţă (obligatoriu) contra manei şi primul - contra făinării, la soiurile aromate rezistente la bolile criptogamice se va aplica în stadiul de ,îndată după înflorit” cu utilizarea produselor pe bază de cupru în dozele indicate mai sus, în combinaţie cu unul dintre produsele pe bază de sulf aplicat în dozele autorizate contra făinării: Thiovit Jet 80 WG - 3,0-4,0 kg/ha, Microthiol Special Disperss - 3,0 $4,0 \mathrm{~kg} / \mathrm{ha}$, Kumulus DF - 3,0-6,0 kg/ha, Sullfet, WG (sulf) - 3,0-6,0 kg/ha, Sulfomat 80 PU (cepa) $3,0 \mathrm{~kg} / \mathrm{ha}$, Cosavet $80 \mathrm{WDG} / 3,0 \mathrm{~kg} / \mathrm{ha}$ ş.a., cu un consum de soluţie de $600 \mathrm{l} / \mathrm{ha}$ [8].

După înflorit, în fazele de „cresterea boabelor”, tratamentele contra manei se vor aplica doar în cazurile apariţiei unor condiţii extrem de favorabile pentru dezvoltarea bolii (ploi de lungă durată, mana manifestă o dezvoltare şi răspândire de pretutindeni la soiurile sensibile). În astfel de cazuri se va lua în considerare că produsele cuprice protejează organele sensibile pentru o perioadă maximă de 7 zile. Tratamentele se vor efectua repetat cu un consum de soluţie de $600 \mathrm{l} / \mathrm{ha}$.

În stadiul când boabele ating mărimea unui bob de mazăre, în combaterea făinării se aplică al doilea tratament de siguranţă cu utilizarea unui produs pe bază de sulf. Se va lua în considerare faptul că sulful trebuie utilizat în limitele temperaturilor $+16-26{ }^{\circ} \mathrm{C}$, deoarece aplicarea acestuia la temperaturi mai joase de $+16{ }^{\circ} \mathrm{C}$ duce la scăderea acțiunii toxice a produsului din cauza lipsei de sublimare (acţiune toxică asupra făinării exercită doar bioxidul de sulf $\left(\mathrm{SO}_{2}\right)$, rezultat din sublimarea sulfului). Utilizarea unor astfel de produse la temperaturi mai înalte de $+26{ }^{\circ} \mathrm{C}$ poate produce arsuri pe organele verzi ale viţei-de-vie. Tratamentele trebuie efectuate seara după ora 18 , când temperatura coboară mai jos de $+25^{\circ} \mathrm{C}$, pentru diminuarea efectului nedorit al arsurilor provocate de sublimarea rapidă a sulfului în bioxid de sulf.

Dacă temperaturile medii zilnice sunt mai joase de $+16{ }^{\circ} \mathrm{C}$ sau depăşesc nivelul de $+26{ }^{\circ} \mathrm{C}$, în combaterea făinării pot fi utilizate unele produse biologice - pe baza bacteriei Pseudominas fluorescens suşa AR (produsul Rizoplan*cu titrul $2-5^{*} 10 \% / \mathrm{ml}$ cu doza de administrare 3,0 l/ha).

Menţionăm că tratamentele cu utilizarea produsului Rizoplan* sunt eficiente în cazul când umiditatea relativă a aerului depăşeşte $60-70 \%$ (odată cu micşorarea umidităţii aerului scade eficacitatea de combatere a produsului). Tratamentele se vor efectua separat, de- 
oarece produsul biologic Rizoplan* nu este compatibil cu produsele cuprice (cuprul inhibă activitatea bacteriei Pseudominas fluorescens).

În stadiul de „înmuiere a boabelor” - „începutul pârgului" (cu 15-25 de zile), înainte de recoltare, se recomandă efectuarea unui tratament de siguranţă cu utilizarea produselor pe bază de cupru în dozele indicate mai sus. Tratamentul este indicat pentru protecţia contra manei şi bacteriozelor (în perioada de pârgă şi după recoltare). Acesta contribuie la coacerea mai bună a lemnului şi sporeşte rezistenţa la condiţiile de iernare a butucilor.

În condiţii favorabile dezvoltării putregaiului-cenuşiu (când după înflorire se înregistrează ploi de lungă durată, se depistează primele simptome ale bolii pe inflorescenţe), în stadiile de după înflorire şi până la compactarea ciorchinelor, se recomandă aplicarea a 1-2 tratamente cu utilizarea preparatelor biologice Gliocladin SC (7,0-10,0 I/ha), Trichodermin SC (7,0$10 \mathrm{~kg} / \mathrm{ha}$ ), permise pentru utilizare în programele de protecţie ecologică [1].

În cazul creării condiţiilor favorabile pentru manifestarea putregaiului-cenuşiu la acumularea a $12-15 \%$ de zahăr în boabe, pentru profilaxia bolii, se recomandă aplicarea procedeului de defoliere parţială a butucilor. Operaţia constă în lichidarea a 2-3 frunze de la baza lăstarilor (până la primul ciorchine). Datorită aerisirii mai bune în interiorul coroanei butucului, dezvoltarea bolii se reduce de 1,5-2 ori, ceea ce conduce la crearea condiţiilor defavorabile dezvoltării putregaiului, acesta fiind un procedeu important în profilaxia bolii [10].

În cazul în care apar condiţii favorabile pentru dezvoltarea putregaiului-cenuşiu în perioada de pârgă, după efectuarea procedeului de desfrunzire parţială, se recomandă aplicarea unui tratament cu utilizarea preparatelor biologice Gliocladin SC sau Trichodermin SC, utilizate în dozele indicate mai sus, respectând cu stricteţe perioada de pauză până la recoltare de 5 zile (http://www.pesticide.md/registruTrichodermină\%2C).

Menţionăm că numai în cazul aplicării complexului întreg de măsuri tehnologice şi de igienă culturală care contribuie la crearea condiţiilor defavorabile dezvoltării bolii, combaterea putregaiului-cenuşiu poate fi eficientă. Se evidenţiază următoarele măsuri şi procedee agrotehnice aplicate culturii, care diminuează riscul apariției infecţiilor şi dezvoltării putregaiului-cenuşiu în plantaţiile viticole şi care sunt factori importanţi în prevenirea atacului provocat de putregaiul-cenuşiu:

- lucrările solului (cultivatul, prăşitul intervalelor dintre butuci (în rând)), aplicate la timp, favorizează dezvoltarea şi îmbunătăţirea stării fiziologice a plantelor. Nimicirea buruienilor conduce la micşorarea higroscopicităţii aerului (aerisirea mai bună a butucilor);

- lucrările în verde au un rol deosebit de important în prevenirea atacului de putregai şi a celorlalte boli sezoniere. Lichidarea lăstarilor de prisos contribuie la micşorarea umidităţii aerului în interiorul butucilor.
Legatul corect al lăstarilor asigură o expoziţie cât mai bună a organelor butucului la soare şi defavorizează atacurile de putregai. Conducerea coardelor se va efectua astfel ca strugurii să nu fie în contact direct sau în apropiata vecinătate cu solul, unde sursa de infecţie este mai mare. Menţionăm că intensitatea slabă a luminii pe fondul higroscopicităţii înalte a aerului şi persistenţei îndelungate a picăturilor de apă pe ciorchini creează cele mai favorabile condiţii pentru atacul de Botrytis cinerea Pers.);

- folosirea echilibrată a îngrăşămintelor minerale; excesul îngrăşămintelor de azot favorizează atacuri mai intense de făinare, iar mai apoi şi de putregaiulcenuşiu. Introducerea la viţa-de-vie a îngrăşămintelor de fosfor şi potasiu contribuie la îngroşarea şi mărirea durităţii pieliţei bobiţei, iar introducerea în exces a îngrăşămintelor de azot favorizează atacurile grave de putregai;

- combaterea la timp a dăunătorilor (moliilor) şi a făinării viţei-de-vie. Atât insectele, cât şi făinarea viţei-de-vie produc crăpături şi leziuni pe bobiţe, creând cele mai favorabile condiţii pentru răspândirea bolii. Este cunoscut faptul că sucul celular, exudat din bobiţele deteriorate, în concentraţie de $12-15 \%$ este cel mai bun substrat pentru germinarea conidiilor de Botrytis cinerea Pers.;

- recoltarea în termen redus a strugurilor, mai ales în condiţii favorabile pentru dezvoltarea bolii. Astfel, rezistenţa complexă la principalele boli criptogamice a noilor soiuri cu arome de muscat permite utilizarea lor în programe ecologice de cultivare şi obţinerea unei noi categorii de producţie vitivinicolă cu denumire ecologică (organică) [1, 2, 9].

\section{Tehnologia prelucrării strugurilor. \\ Evaluarea şi valorificarea potenţialului aromatic al vinurilor obţinute din soiurile autohtone cu arome de muscat}

Procesele tehnologice în prelucrarea strugurilor din grupa Muscat vizează, de regulă, utilizarea maximă a potenţialului aromatic al strugurilor şi conservarea acestuia în timpul procesului tehnologic. Metodele tradiţionale care permit utilizarea potenţialului aromatic al strugurilor din grupa Muscat sunt: macerarea bioxidului de carbon, criomacerarea, macerarea clasică, tratamentul termic.

Tendinţa de oxidare excesivă a complexului aromatic din vinurile tinere este una dintre caracteristicile vinurilor-materie primă obţinute din soiurile aromatice. În legătură cu aceasta, pe parcursul procesului tehnologic este necesară monitorizarea cu regularitate a conţinutului de $\mathrm{SO}_{2}$ în vinuri. Pentru a preveni procesele de oxidare, se recomandă de menţinut conţinutul total de $\mathrm{SO}_{2}$ în vin în proporţie de $100-140 \mathrm{mg} / \mathrm{dm}^{3}$, iar al celui liber - de $20-30 \mathrm{mg} / \mathrm{dm}^{3}$, prin sulfitaţii suplimentare cu doze de $20-25 \mathrm{mg} / \mathrm{dm}^{3} \mathrm{SO}_{2}$ (la necesitate), după fiecare etapă şi pe tot parcursul desfăşurării procesului tehnologic. 
Unul dintre obiectivele de bază ale prezentei lucrări a fost şi valorificarea potenţialului aromatic al soiurilor de struguri de tip muscat de selecţie autohtonă în vederea evidenţierii şi obţinerii unor vinuri inedite, originale cu calităţi autentice specifice zonei de producere a vinului.

Cercetările efectuate până în prezent au demonstrat că tipicitatea vinurilor de tip muscat este influenţată în principal din derivații terpenici (amestecuri de substanţe volatile), care în cazul soiurilor aromate se acumulează în celulele pieliţei boabelor şi în straturile adiacente acesteia (în pulpa bobiţelor).

$\mathrm{Pe}$ baza studiului unor factori tehnologici care influenţează conţinutul terpenelor, s-au constatat următoarele:

a) conţinutul de terpene în must se măreşte semnificativ odată cu creşterea duratei macerării, concentraţia maximă fiind înregistrată după 6-8 ore de macerare;

b) conţinutul de terpene se mărește odată cu creşterea temperaturii procesului de macerare. Astfel, s-a demonstrat că odată cu creşterea duratei şi temperaturii procesului de macerare (de la $10-12^{\circ} \mathrm{C}$ până la $18-20^{\circ} \mathrm{C}$ ) se accelerează procesele oxidative ale vinurilor albe seci obţinute din soiurile de struguri de tip muscat. Durata optimă a procesului de macerare este de 8 ore, iar temperatura se încadrează în limite de la 14 la $16{ }^{\circ} \mathrm{C}$.

Utilizarea enzimelor pectolitice în procesul de macerare a făcut posibilă creşterea conţinutului de terpene (cu $0,6 \mathrm{mg} / \mathrm{dm}^{3}$ ) şi a contribuit la creşterea conţinutului de aldehide şi a potenţialului redox al vinurilor muscat.

Studiul dinamicii compuşilor aromatici pe parcursul perioadei de fermentaţie $\left(16-18^{\circ} \mathrm{C}\right)$ a arătat o scădere treptată a concentraţiei terpenelor legate (precursorilor nevolatili) în prima jumătate a acestui proces şi o uşoară creştere în cea ulterioară.

Concentraţia compuşilor terpenici liberi a fost în scădere pe tot parcursul procesului de fermentare, la o rată mai mare în primele 6 zile. În timpul fermentaţiei, concentraţia de substanţe volatile a crescut semnificativ pe întreaga durată a procesului de fermentare.

Alcoolii superiori au prezentat o rată de creştere ridicată în primele 10 zile (cu o majorare a concentraţiei de la 6 la $138 \mathrm{mg} / \mathrm{dm}^{3}$ ). Aldehidele au prezentat o creştere mică, dar stabilă: de la 11 la $17 \mathrm{mg} / \mathrm{dm}^{3}$. Esterii au arătat o creştere medie a concentraţiei lor, de la 7 la $48 \mathrm{mg} / \mathrm{dm}^{3}$.

Astfel, s-a constatat că procesele tehnologice de prelucrare a strugurilor din grupa Muscat de selecţie nouă au un impact semnificativ asupra conţinutului de substanţe aromatice şi asupra indicilor organoleptici ai vinurilor finite.

\section{CONCLUZII}

1. În Republica Moldova pe parcursul a mai mult de 50 de ani s-au creat şi au fost introduse în producţie diverse soiuri de selecţie nouă, inclusiv o serie de soiuri aromatice cu rezistenţă complexă la factorii biotici (boli) şi abiotici (ger şi fluctuaţiile de temperatură din timpul iernii), care întrunesc cerinţele necesare pentru obţinerea vinurilor de calitate cu aromă de muscat.

2. Soiurile noi aromatice de selecţie moldovenească Viorica, Muscat de laloveni, Muscat basarabean, Muscat de Onițcani ş.a. posedă rezistenţă sporită la ger, condiţiile de iernare şi la principalele boli criptogamice. Pot fi cultivate în cultură neprotejată pe tulpină înaltă, asigură recolte stabile şi de calitate pentru fabricarea unor vinuri performante, permit folosirea redusă a pesticidelor la hectar cu efecte avantajoase din punct de vedere ecologic şi economic (diminuează poluarea mediului ambiant, micşorează costul producţiei).

3. Factorii de impact pentru obţinerea unor recolte stabile şi de calitate la cultivarea soiurilor aromatice sunt: amplasarea plantaţiilor pe pante călduroase, protejate de vânturile din nord-vest şi cu o bună circulaţie şi scurgere a aerului rece; efectuarea calitativă a lucrărilor de îngrijire cu respectarea tehnologiei de cultură, fondarea plantaţiilor cu material sănătos liber de boli virotice şi micoplasmatice, alegerea corectă a formei butucilor, crearea de butuci sănătoşi, fără răni excesive, cu o rezervă bună de lemn multianual, atribuirea unor sarcini optime cu lăstari şi rod (evitarea sarcinilor suboptimale sau a supraîncărcării butucilor cu lăstari şi rod).

4. Calităţile deosebite şi rezistenţa la factorii biotici şi abiotici a soiurilor noi aromatice de selecţie moldovenească pot fi utilizate în programe ecologice de producţie vitivinicolă cu folosirea limitată a sărurilor simple pe bază de sulf şi cupru în conformitate cu principiile de agricultură ecologică, elaborate de Federaţia Internaţională a Mişcărilor pentru Agricultură Ecologică (IFOAM).

5. În baza datelor obţinute şi a valorificării potenţ̧ialului aromatic al soiurilor de struguri de tip muscat de selecţie autohtonă a fost indicată (recomandată) modificarea unor parametri în procesul tehnologic de prelucrare a strugurilor (durata şi temperatura desfăşurării procedeului de macerare a boştinei, în funcţie de regiunile viticole), cu efecte pozitive asupra conţinutului de substanţe aromatice şi asupra indicilor organoleptici ai vinurilor finite.

6. S-a demonstrat că odată cu creşterea duratei şi temperaturii procesului de macerare (de la $10-12{ }^{\circ} \mathrm{C}$ până la $18-20^{\circ} \mathrm{C}$ ) se accelerează procesele oxidative ale vinurilor albe seci obţinute din soiurile de struguri de tip muscat. Durata optimă a procesului de macerare este de 8 ore, iar temperatura se încadrează în limite de la 14 la $16{ }^{\circ} \mathrm{C}$.

7. Tipicitatea vinurilor de tip muscat este influenţată în principal din derivații terpenici (substanţe aromatice) care, în cazul soiurilor aromate, se acumulează în celulele pieliţei boabelor şi în straturile adiacente acesteia (în pulpa bobiţelor). Conţinutul de terpene în must se măreşte semnificativ odată cu creşterea duratei macerării, concentraţia maximă a acestora fiind înregistrată după 6-8 ore de macerare. Conţinutul de terpene se mărește odată cu creşterea temperaturii procesului de macerare. 
8. A fost obţinută suşa de drojdie INVV-23, care, fiind utilizată în procesul de fermentare, a dat posibilitatea obţinerii (sintetizării) unor concentraţii mai sporite de compuşi terpenici şi a celor mai mici cantităţi de alcooli superiori, esteri şi aldehide, cu impact pozitiv asupra aromaticii vinurilor din soiurile de muscat - factor important în obţinerea producţiei vinicole de înaltă calitate, competitivă pe pieţele externe şi interne.

\section{BIBLIOGRAFIE}

1. Cebanu V., Gaina B., Cuharschi M., Degteari V., Midari A., Chiaburu, Elena, Armaşu, Svetlana, Terteac D., IŞPHTA; Volosciuc L., Voineac V., Institutul de Genetică, Fiziologie şi Protecţia Plantelor. Recomandări de combatere a putregaiului-cenuşiu al viţei-de-vie în agricultura ecologică. În: Pomicultura, Viticultura şi Vinificaţia, nr. 3 [75], 2018, p. 16-19.

2. Nedov P., Degteari V., Cebanu V., Lucic P. Contribuţii privind combaterea manei viţei-de-vie conform principiilor agriculturii biologice, bazate pe utilizarea produselor noi cuprice, în vederea obţinerii producţiei vitivinicole pure. In Wine 2006. Materialele Conferinţei Internaţionale Ştiinţifico-Practice, 20-21 februarie 2006, Chişinău, „Poliproject Exihibitions LTD", p. 28-30.

3. Rusu E., Gaina B., Obadă L., Craveţ N., Dumanov V. Crearea identităţii vinurilor moldoveneşti prin promovarea soiurilor noi de selecţie. Conferinţa Internaţională „Realizări inovative în domeniul vitivinicol”, 18-19 sept. 2008, Chişinău, p. 165-166.
4. Taran N., Soldatenco E. Tehnologia vinurilor spumante. Aspecte moderne. Chişinău, 2011, 302 p.

5. Макаров С.Н. Научные основы методики опытного дела в виноградарстве. «Методика учета урожая и элементов грозди». «Учет среднего веса грозди» // Тр. Молдавского НИИ садоводства, виноградарства и виноделия, Кишинев, 1964, Т.IX, с. 150-154.

6. Недов П.Н. и др. Новые методы фритопатологических и иммунологических исследований в виноградарстве. Кишинев, изд-во «Штиинца», 1985, с. 137.

7. Таран Н.Г. О влиянии на содержание терпеновых веществ в сухих винах из сорта Мускат белый. În: „Lider-Agro”, № 11-12, 2020, с. 16-21.

8. Чебану В., Дегтярь В. Влияние объема расхода рабочей жидкости на эфффективность мероприятий борьбы с милдью винограда с учетом способа действия применяемых фрунгицидов. Материалы науч. практич. конфр. посвященной 70-летию ВНИИВиВ им. Я.И. Потапенко, Новочеркасск, 2006, с. 132-139.

9. Чебану В.А., Кухарский М.С., Дегтеарь В.Н., Мидарь А.И. Оптимизация сроков проведения частичной десолиации виноградных кустов, как метод профилактики развития серой гнили. В: Виноградарство і Виноробство. Міжвідомчий тематичнний науковий збірник. Випуск 47 ННЦ «Інститут Виноградарства і Виноробства ім В.Е. Таірова», Одесса, 2010, с. 194-199.

RECENZIE ŞTIINȚIFICĂ - Simion UNGUREANU, doctor în știtinte agricole.

Materialul a fost prezentat la 27.08.2021. 